\title{
Assessing Indices for Predicting Potential Nitrogen Mineralization in Soils under Different Management Systems
}

\author{
Harry H. Schomberg* \\ USDA-ARS \\ J. Phil Campbell, Sr. \\ Natural Resource Conservation Center \\ Watkinsville, GA 30677 \\ Sirio Wietholter \\ Empresa Brasileira de Pesquisa Agropecuária (Embrapa Trigo \\ Passo Fundo \\ Rio Grande do Sul, Brazil 99001-970 \\ Timothy S. Griffin ${ }^{1}$ \\ Friedman School of Nutrition Sci. and Policy \\ Tufts Univ. \\ Boston, MA 02111 \\ D. Wayne Reeves \\ USDA-ARS \\ J. Phil Campbell, Sr. \\ Natural Resource Conservation Center \\ Watkinsville, GA 30677
}

Miguel L. Cabrera

Univ. of Georgia

Dep. of Crop and Soil Sciences

Athens, GA 30602

Dwight S. Fisher

Dinku M. Endale

USDA-ARS

J. Phil Campbell, Sr.

Natural Resource Conservation Center

Watkinsville, GA 30677

Jeff M. Novak

USDA-ARS

Coastal Plains Soil, Water, and Plant Res.Ctr.

Florence, SC 29501

Kip S. Balkcom

Randy L. Raper

USDA-ARS

National Soil Dynamics Lab.

Auburn, AL 36832

Newell R. Kitchen

USDA-ARS

Cropping Systems and Water Quality Res. Unit

Columbia, MO 65211

\section{Martin A. Locke \\ USDA-ARS \\ National Sedimentation Lab. \\ Oxford, MS 38655}

Kenneth N. Potter

USDA-ARS

Grassland Soil and Water Res. Lab.

Temple, TX 76502

\section{Robert C. Schwartz}

USDA-ARS

Southern Plains Conserv.Production Rese. Lab.

Bushland, TX 79012

\section{Clinton C. Truman}

USDA-ARS

Southeast Watershed Res. Lab.

Tifton, GA 31793

Don D. Tyler

Univ. of Tennessee

Biosystems Engineering and Soil Science Dep.

Jackson, TN 38301
A reliable laboratory index of $\mathrm{N}$ availability would be useful for making $\mathrm{N}$ recommendations, but no single approach has received broad acceptance across a wide range of soils. We compared several indices over a range of soil conditions to test the possibility of combining indices for predicting potentially mineralizable $\mathrm{N}\left(\mathrm{N}_{0}\right)$. Soils $(0-5$ and $5-15 \mathrm{~cm})$ from nine tillage studies across the southern USA were used in the evaluations. Long-term incubation data were fit to a first-order exponential equation to determine $\mathrm{N}_{0}, k$ (mineralization rate), and $\mathrm{N}_{0}{ }^{*}\left(\mathrm{~N}_{0}\right.$ estimated with a fixed $k$ equal to $\left.0.054 \mathrm{wk}^{-1}\right)$. Out of 13 indices, five [total C (TC), total $\mathrm{N}$ (TN), $\mathrm{N}$ mineralized by hot $\mathrm{KCl}$ (Hot_N), anaerobic N (Ana_N), and N mineralized in $24 \mathrm{~d}$ (Nmin_24)] were strongly correlated to $\mathrm{N}_{0}(r>0.85)$ and had linear regressions with $r^{2}>0.60$. None of the indices were good predictors of $k$. Correlations between indices and $\mathrm{N}_{0}{ }^{*}$ improved compared with $\mathrm{N}_{0}$, ranging from $r=0.90$ to 0.95 . Total $\mathrm{N}$ and flush of $\mathrm{CO}_{2}$ determined after $3 \mathrm{~d}$ (Fl_CO2) produced the best multiple regression for predicting $\mathrm{N}_{0}\left(R^{2}=0.85\right)$ while the best combination for predicting $\mathrm{N}_{0}{ }^{*}\left(R^{2}=0.94\right)$ included TN, Fl_CO2 Cold_N, and $\mathrm{NaOH}$ _N. Combining indices appears promising for predicting potentially mineralizable $\mathrm{N}$, and because TN and $\mathrm{Fl} \_\mathrm{CO} 2$ are rapid and simple, this approach could be easily adopted by soil testing laboratories.

Abbreviations: Ana_N, anaerobic $\mathrm{N}$ mineralization; TC, total carbon; Ca_hypcl, calcium hypochlorite; Cold_N, $\mathrm{KCl}$ extractable $\mathrm{NO}_{3}-\mathrm{N}$; $\mathrm{CT}$, conventional tillage; $\mathrm{Fl} \_\mathrm{CO} 2$, flush of $\mathrm{CO}_{2}$ during $3 \mathrm{~d}$; Hot_N, hot $\mathrm{KCl}$ extractable $\mathrm{NH}_{4}-\mathrm{N} ; \mathrm{Hyd} \_\mathrm{N}$, hydrolyzable $\mathrm{N} ; k$, mineralization rate constant; TN, total nitrogen; $\mathrm{NaOH}_{-} \mathrm{N}$, sodium hydroxide distillable $\mathrm{N} ; \mathrm{N}_{0}$, potentially mineralizable $\mathrm{N} ; \mathrm{N}_{0}{ }^{*}$, value of $\mathrm{N}_{0}$ determined using a fixed value for $k$; Nmin_ 24, N mineralization during $24 \mathrm{~d}$; NP, not plowed (prairie soil); NT, no-Tillage; NT+SS, no-tillage with noninversion subsurface deep tillage; PB_N, phosphate-borate distillable N; POMC, particulate organic matter C; POMN, particulate organic matter N; SM, stubble mulch tillage (sweeps to undercut weeds); ST, strip tillage (in-row subsoil for disruption of subsurface pan and coulters for preparation of narrow strip of tilled soil).

A vailability of $\mathrm{N}$ from soil organic matter during a growing sea$\mathrm{A}_{\text {son is a function of many biotic and abiotic factors, including }}$ cropping history, management, climate (temperature and water availability), and the interacting effects of soil C cycling (Griffin, 2008). Estimating the $\mathrm{N}$ mineralization potential of a soil is of considerable importance for maximizing $\mathrm{N}$-use efficiency from all $\mathrm{N}$ sources and minimizing environmental losses. Efforts to develop quick biological or chemical methods for identifying the mineralization potential of organic $\mathrm{N}$ have a long history (reviewed by Bremner, 1965; Keeney, 1982; Bundy and Meisinger, 1994; Griffin, 2008) with various levels of success. Several of these methods closely correspond to the mineralizable N component (Griffin, 2008).

${ }^{1}$ Formerly at USDA-ARS, New England Plant, Soil and Water Res. Lab., Orono, ME 04469

Soil Sci. Soc. Am. J. 73:1575-1586

doi:10.2136/sssaj2008.0303

Received 23 Sept. 2008.

*Corresponding author (harry.schomberg@ars.usda.gov).

(c) Soil Science Society of America

677 S. Segoe Rd. Madison WI 53711 USA

All rights reserved. No part of this periodical may be reproduced or transmitted in any form or by any means, electronic or mechanical, including photocopying, recording, or any information storage and retrieval system, without permission in writing from the publisher. Permission for printing and for reprinting the material contained herein has been obtained by the publisher. 
Stanford and Smith (1972) established the concept of potentially mineralizable $\mathrm{N}\left(\mathrm{N}_{0}\right)$ as a quantifiable soil $\mathrm{N}$ pool. They used the biologically based, long-term aerobic incubation method to measure net $\mathrm{N}$ mineralization over $210 \mathrm{~d}$ to estimate $\mathrm{N}_{0}$ along with the $\mathrm{N}$ mineralization rate constant $(k)$ using a firstorder exponential function:

$$
\mathrm{N}_{\mathrm{t}}=\mathrm{N}_{0}\left(1-\mathrm{e}^{-k t}\right)
$$

where $\mathrm{N}_{\mathrm{t}}$ is the cumulative $\mathrm{N}$ mineralized at Week $t, \mathrm{~N}_{0}$ is the maximum mineralizable $\mathrm{N}, k$ is the mineralization rate constant (expressed on a wk ${ }^{-1}$ basis), and time $(t)$ in weeks. This is the standard method against which most others are assessed, and it has been widely used for evaluating environmental, soil, and management impacts on $\mathrm{N}$ mineralization.

A second widely adopted approach used to identify the pool of potentially mineralizable $\mathrm{N}$ and compare more rapid laboratory methods is short-term anaerobic incubation (Waring and Bremner, 1964). This procedure quantifies the $\mathrm{NH}_{4}-\mathrm{N}$ released from microbes killed by the anoxic conditions in a soil-water slurry incubated for 7 or $14 \mathrm{~d}$ under anaerobic conditions. Gianello and Bremner (1986b) observed a correlation $(r)$ of 0.96 between a 7-d anaerobic incubation and net $\mathrm{N}$ mineralized during an 84-d aerobic incubation for a range of soils from Iowa, USA. Results from Chan (1997) for pasture and cropland soils show a strong relationship between these two methods $(r=0.94)$, and also shows that $\mathrm{N}_{0}$ was approximately 2.25 times the amount of $\mathrm{N}$ released during the anaerobic incubation.

Total soil N (and C) concentration has been used as an index of $\mathrm{N}$ availability for plant growth with mixed results. In some cases, the relationship is significant, but not strong enough to be predictive. Hassink (1994) and Selles et al. (1999) observed weak correlations between TN concentration and $\mathrm{N}$ mineralization for soils assessed from a broad geographical area, while Marion et al. (1981), Hadas et al. (1986a; 1986b), Gianello and Bremner (1986b), and Springob and Kirchmann (2003) observed much stronger relationships when soils originated from a small geographical area.

A variety of chemical extraction and distillation methods for $\mathrm{N}$ availability have been developed, including extraction in weak salt solutions (Keeney and Bremner, 1966), stronger salt solutions (Gianello and Bremner, 1986a; 1986b) and alkali hydrolysis in $\mathrm{NaOH}$ (Stanford, 1978). Of these methods, extraction with hot or cold $\mathrm{KCl}$ (Hot_N or Cold_N) and distillation of $\mathrm{NH}_{4}-\mathrm{N}$ with either a $\mathrm{pH} 11.2$ phosphate-borate buffer solution $\left(\mathrm{PB} \_\mathrm{N}\right)$ or a $\mathrm{NaOH}$ solution $\left(\mathrm{NaOH} \_\mathrm{N}\right)$ have shown promise. Øien and Selmer-Olsen (1980) and Whitehead (1981) proposed using hot $\mathrm{KCl}$-extractable $\mathrm{NH}_{4}-\mathrm{N}$ as an index of available $\mathrm{N}$ on the basis of a close correlation with plant $\mathrm{N}$ uptake. Gianello and Bremner (1986a) found $\mathrm{N}$ mineralization and hot $\mathrm{KCl}-$ extractable $\mathrm{NH}_{4}-\mathrm{N}$ corrected for initial mineral $\mathrm{N}$ (hydrolyzable N, Hyd_N) were highly correlated $(r=0.95)$. Other reports have found smaller correlations (Groot and Houba, 1995; Selles et al., 1999; Curtin and Wen, 1999; Jalil et al., 1996). Curtin and Wen (1999) and Jalil et al. (1996) found the correlation between hot $\mathrm{KCl}$-extractable $\mathrm{NH}_{4}-\mathrm{N}$ and $\mathrm{N}_{0}$ was much stronger when values were not corrected for the initial $\mathrm{NH}_{4}-\mathrm{N}$ concentration extracted in cold $\mathrm{KCl}$.

Gianello and Bremner (1986b, 1988) observed a strong correlation between mineralizable N and PB_N. They proposed that PB_N measures a combination of $\mathrm{NH}_{4}-\mathrm{N}$ and some amino acids. Jalil et al. (1996) found the correlation between $\mathrm{N}_{0}$ and PB_N was similar to the correlation with Hot_N $(r=0.78$ and 0.73 , respectively) for 42 soils representing all agroecological regions in Saskatchewan, Canada. When narrowed to a comparison of long-term cropping treatments within one soil type, the correlations increased to 0.92 and 0.88 , respectively. Vanotti et al. (1995) showed that correlations with PB_N were good for field indicators of $\mathrm{N}$ availability, and laboratory-measured labile fractions of soil organic matter, with most having $r>0.70$.

Sharifi et al. (2007) recently proposed assessing potentially available $\mathrm{N}$ with a modification of the $\mathrm{NaOH}$ distillation method (NaOH_N) evaluated by Stanford (1978). Sharifi et al. (2007) found that $\mathrm{NaOH}$ _N was significantly correlated with both $\mathrm{N}$ mineralized after a 24-wk aerobic incubation $(r=0.61)$ and the Illinois soil N test ( $r=0.92$; ISNT; Khan et al., 2001). Bushong et al. (2007) found $\mathrm{NaOH}_{-} \mathrm{N}$ and ISNT were highly correlated $(r=0.90)$ for 25 soils from agricultural sites across the South-Central and Midwest USA. Both indices had similar correlations with potential $\mathrm{N}$ mineralization $(r=0.60)$ measured by anaerobic incubation.

Although no single $\mathrm{N}$ availability index has proven robust enough for broad acceptance, continued work is essential to accumulate critical experimental evidence across a wide range of soils to help identify appropriate procedures (Balkcom et al., 2003). Gallagher and Bartholomew (1964) found that predictions of $\mathrm{N}$ availability were improved when $\mathrm{N}$ test methods and soil properties were combined in multiple regressions. Wang and Li (1991) also found that combining indices improved predictions of plant $\mathrm{N}$ uptake. Chalk and Waring (1970) on the other hand reported little improvement in relationships from combining individual measurements in multiple regressions for predicting $\mathrm{N}$ availability.

Economic and environmental concerns continue to reinforce the need for routine methods of estimating $\mathrm{N}$ availability similar to methods for phosphorus, potassium, and other nutrients. Soil testing laboratories could use a reliable index as a basis for more accurate recommendations of fertilizer N. Our objective was to evaluate the potential for developing a rapid $\mathrm{N}$ assessment tool using $\mathrm{N}$ indices, either individually or in combinations, to predict potential $\mathrm{N}$ availability over a range of pedogenically distinct soils from the southern region of the USA.

\section{MATERIALS AND METHODS Soils}

Several methods for assessing potential $\mathrm{N}$ availability (Table 1) were evaluated using soil samples collected from nine sites in the southern USA (Table 2). Tillage treatments and the crop before sampling are presented in Table 2. Sites were chosen to represent a range of parent materials under different management systems. Eight of the sites included comparisons between conservation tillage and more intensive tillage practices, while one location provided comparison between a non-disturbed prairie and a conservation tillage system. All soils were sampled in late winter before planting the 2005 summer crop by compositing four to eight samples collected from the 0 - to 5 - and the 5- to 15 -cm depths. At each location, approximately $5 \mathrm{~kg}$ of soil was collected and dried at $40^{\circ} \mathrm{C}$ to achieve constant moisture conditions before shipping to Watkinsville, GA. Soils were slightly crushed to pass through a $4.75-\mathrm{mm}$ sieve, and dried at $40^{\circ} \mathrm{C}$ an additional $3 \mathrm{~d}$. Soils were stored at 
Table 1. Laboratory methods used for determining potential $\mathrm{N}$ mineralization.

\begin{tabular}{|c|c|c|c|c|}
\hline Measurement & Abbreviation & Type & Units & Reference \\
\hline Total Carbon & TC & Chemical & $\mathrm{g} \mathrm{kg}^{-1}$ & Bremner, 1996 \\
\hline Total Nitrogen & $\mathrm{TN}$ & Chemical & $\mathrm{mg} \mathrm{kg}^{-1}$ & Nelson and Sommers, 1996 \\
\hline Particulate organic matter C & POMC & Chemical & $\mathrm{mg} \mathrm{kg}^{-1}$ & Franzluebbers et al., 2000 \\
\hline Particulate organic matter $\mathrm{N}$ & POMN & Chemical & $\mathrm{mg} \mathrm{kg}^{-1}$ & Franzluebbers et al., 2000 \\
\hline $\mathrm{KCl}$ extractable $\mathrm{NO}_{3}-\mathrm{N}$ & Cold_N & Extraction & $\mathrm{mg} \mathrm{kg}^{-1}$ & Mulvaney, 1996 \\
\hline Hot $\mathrm{KCl}$ extractable $\mathrm{NH}_{4}-\mathrm{N}$ & Hot_N & Extraction & $\mathrm{mg} \mathrm{kg}^{-1}$ & Gianello and Bremner, 1986a \\
\hline Hydrolyzable N & Hyd_N & Extraction & $\mathrm{mg} \mathrm{kg}^{-1}$ & Gianello and Bremner, 1986a \\
\hline Sodium Hydroxide distillable N & $\mathrm{NaOH} \_\mathrm{N}$ & Distillation & $\mathrm{mg} \mathrm{kg}^{-1}$ & Sharifi et al., 2007 \\
\hline Phosphate-borate distillable $\mathrm{N}$ & PB_N & Distillation & $\mathrm{mg} \mathrm{kg}^{-1}$ & Gianello and Bremner, 1986a, 1988 \\
\hline Anaerobic $\mathrm{N}$ mineralization & Ana_N & Incubation & $\mathrm{mg} \mathrm{kg}^{-1}$ & Waring and Bremner, 1964 \\
\hline $\mathrm{N}$ mineralization during $24 \mathrm{~d}$ & Nmin_24 & Incubation & $\mathrm{mg} \mathrm{kg}-1$ & Franzluebbers et al., 2000 \\
\hline Flush of $\mathrm{CO}_{2}$ during $3 \mathrm{~d}$ & Fl_CO2 & Incubation & $\mathrm{mg} \mathrm{kg}^{-1}$ & Franzluebbers et al., 2000 \\
\hline Calcium hypochlorite & Ca_hypcl & Chemical & $\mathrm{kPa}$ & Picone et al., 2002 \\
\hline
\end{tabular}

room temperature after drying. For the laboratory methods, soils were passed through a 2-mm sieve, and three replicate samples were assayed with each method except for the distillation procedures in which two replicates were used.

Routine soil analyses ( $\mathrm{pH}$ and plant nutrients) were conducted at the University of Georgia Soil, Plant, and Water Analysis Laboratory (Athens, GA). Total $\mathrm{C}$ and $\mathrm{N}$ were determined by dry combustion using a TruSpec CN analyzer (LECO Corporation, St. Joseph, MI). For the Temple soils, inorganic $\mathrm{C}$ was determined gravimetrically from loss of $\mathrm{CO}_{2}$ following treatment with acid (J.B. Rodriguez, 2008, personal communication). Sand, silt, and clay were determined by the procedure of Kettler et al. (2001). The sand fraction (>0.05-mm diam.) was ball milled, and $\mathrm{C}$ and $\mathrm{N}$ were determined by dry combustion to estimate particulate organic matter $\mathrm{C}$ and $\mathrm{N}$ (POMC and POMN, respectively) per gram of air-dry soil (Franzluebbers et al., 2000).

\section{Nitrogen Mineralization Indices Long-Term Incubation}

A modification of the non-leached approach of Wang et al. (2003) was used in the long-term ( $41 \mathrm{wk}$ ) incubation for determining $\mathrm{N}_{0}$ and $k$. Soils were weighed $(10 \mathrm{~g})$ in triplicate into $50 \mathrm{~mL}$ centrifuge tubes, and water was added to reach $50 \%$ water filled pore space. Samples were incubated in a large chamber at $35^{\circ} \mathrm{C}$. They were kept inside closed plastic boxes containing six vials of water to help maintain humidity. Boxes were open two to three times each week for ventilation, and their positions inside the chamber were re-randomized. Water content was adjusted every 3 wk by weighing and adding water to replace losses due to evaporation. Mineral $\mathrm{N}$ was extracted at Weeks 0, 2, 4, 6, 9, 12, 16, 20 , $24,29,35$, and 41 by adding $40 \mathrm{~mL}$ of $2 \mathrm{~mol} \mathrm{~L}^{-1} \mathrm{KCl}$, shaking for $1 \mathrm{~h}$, and filtering through Whatman No. 42 filter paper. Extracts were frozen until analyzed for $\mathrm{NO}_{3}-\mathrm{N}$ and $\mathrm{NH}_{4}-\mathrm{N}$ on an automated analyzer (Keeney and Nelson, 1982). Cumulative $\mathrm{N}$ mineralized was calculated by summing the measured $\mathrm{NO}_{3}-\mathrm{N}$ and $\mathrm{NH}_{4}-\mathrm{N}$ for each sampling date. Initial mineral $\mathrm{N}$ content at Time 0 was not subtracted from values measured on subsequent dates. We used this approach because the flush of $\mathrm{N}$ released on rewetting of the soil would most likely be readily immobilized and mineralized at an unknown rate over the course of the incubation. The data from weeks 2 to 41 were used to calculate $\mathrm{N}_{0}$ and $k$ in Eq. 1 with the MODEL procedure of the Statistical Analysis System (SAS) version 9.2 (SAS Institute Inc., 2008). Parameters were fit by site, tillage treatment, and depth using nonlinear regression. The use of a fixed value of $k\left(0.054 \mathrm{wk}^{-1}\right)$ in the single exponential model for determining $\mathrm{N}_{0}\left(\mathrm{~N}_{0}{ }^{*}\right)$, as proposed by Wang et al. (2003), was ex- plored and determined with the same model fitting procedures. Wang et al. (2003) used the average value of $k$ determined by Stanford and Smith (1972) for 39 soils, to eliminate the effects of the colinearity of parameters when simultaneously fitting $\mathrm{N}_{0}$ and $k$, and to allow $\mathrm{N}_{0}$ to be a distinct indicator of the size of the potentially mineralizable $\mathrm{N}$ pool directly comparable among soils.

\section{Extractable Inorganic Nitrogen (Cold_N)}

The Week 0 soils of the long-term incubation were used for determining the initial amount of $\mathrm{NO}_{3}-\mathrm{N}$ in soils. Ten grams of soil were extracted with $40 \mathrm{~mL}$ of $2 \mathrm{~mol} \mathrm{~L}^{-1} \mathrm{KCl}$, and designated as Cold_N. The $\mathrm{NH}_{4}-\mathrm{N}$ (Cold_NH ${ }_{4}$ ) determined in the same extract was used as the initial value for calculation of some of the indices below.

\section{Hydrolyzable (Hyd_N) and Hot (Hot_N) $\mathrm{KCl}$ Extractable $\mathrm{NH}_{4}$}

Hot extractable N (Gianello and Bremner, 1986b) was determined by weighing $3 \mathrm{~g}$ of soil into a 50 - $\mathrm{mL}$ centrifuge tube, adding $20 \mathrm{~mL}$ of $2 \mathrm{~mol} \mathrm{~L}^{-1} \mathrm{KCl}$, and incubating the samples at $100^{\circ} \mathrm{C}$ for $4 \mathrm{~h}$ in a water bath. After cooling to room temperature, the samples were filtered, and the extracts were frozen for $\mathrm{NH}_{4}-\mathrm{N}$ analysis as described above. Hydrolyzable N (Hyd_N) was calculated by subtracting Cold_NH 4 (above) from $\mathrm{NH}_{4}-\mathrm{N}$ released by heating (Gianello and Bremner, 1986b). Jalil et al. (1996) and Curtin and Wen (1999) reported a better correlation with mineralizable $\mathrm{N}$ when the initial $\mathrm{NH}_{4}-\mathrm{N}$ is not subtracted, which we designated as Hot_N.

\section{Sodium Hydroxide Distillable Nitrogen}

Soils were analyzed for $\mathrm{NaOH}$ _N following the Sharifi et al. (2008) modification of the method developed by Stanford (1978). A 5-g soil sample was added to a distillation flask with $40 \mathrm{~mL}$ of $12.5 \mathrm{~mol} \mathrm{~L}^{-1}$ $\mathrm{NaOH}$, and distilled until $40 \mathrm{~mL}$ was collected in $5 \mathrm{~mL}$ of $4 \%(\mathrm{w} / \mathrm{v})$ boric acid solution. The volume extracted was used as the determining factor for ending the distillation rather than time due to slight differences in the rate of steam delivery between the two distillation units. The $\mathrm{NH}_{4}-\mathrm{N}$ content of the distillate was determined from titration with a standard solution of $0.005 \mathrm{~mol} \mathrm{~L}^{-1} \mathrm{HCl}$ in the presence of a mixed indicator (bromocresol green and methyl red).

\section{Phosphate-Borate Distillable Nitrogen}

The PB_N was determined as described by Gianello and Bremner (1988). A 4-g soil sample was direct steam distilled with $40 \mathrm{~mL}$ of phosphate- 
borate buffer $(\mathrm{pH}=11.2)$ to obtain $40 \mathrm{~mL}$ of distillate, and the $\mathrm{NH}_{4}-\mathrm{N}$ content determined as in the $\mathrm{NaOH} \_\mathrm{N}$ procedure.

\section{Short-Term Anaerobic Incubation}

Ammonium released during anaerobic incubation was determined following the method of Keeney and Bremner (1966). A 5-g soil sample was placed in a $16 \times 150 \mathrm{~mm}$ (outer size) screw capped test tube, and $12.5 \mathrm{~mL}$ of water added to limit headspace inside the test tube. Caps were securely fastened to ensure anaerobic conditions. After $7 \mathrm{~d}$ of incubation at $40^{\circ} \mathrm{C}$, samples were transferred to a $50-\mathrm{mL}$ centrifuge tube by rinsing with $12.5 \mathrm{~mL}$ of $4 \mathrm{~mol} \mathrm{~L}^{-1} \mathrm{KCl}$. Samples were shaken $30 \mathrm{~min}$ on a horizontal reciprocating shaker, filtered through a Whatman No. 42 filter paper, and extracts were frozen until analysis for $\mathrm{NH}_{4}-\mathrm{N}$. The amount of $\mathrm{N}$ mineralized during the 7-d incubation was calculated by subtracting Cold_NH $\mathrm{NH}_{4}$.

\section{Three Day Flush of Carbon Dioxide}

The $\mathrm{CO}_{2}$ released from soil during a 3-d incubation was determined by the procedure of Franzluebbers et al. (2000). Soils $(40 \mathrm{~g})$ were weighed into a $60-\mathrm{mL}$ glass vial, and adjusted to $50 \%$ water-filled pore space. Soils were incubated at $25^{\circ} \mathrm{C}$ inside a $1-\mathrm{L}$ wide-mouth canning jar with a vial of water $\left(10 \mathrm{~mL}\right.$ ) and a vial with $10 \mathrm{~mL}$ of $1 \mathrm{~mol} \mathrm{~L}^{-1} \mathrm{NaOH}$ (for capturing $\mathrm{CO}_{2}$ ). Jars were sealed with a screw cap lid. The quantity of $\mathrm{CO}_{2}$ evolved was determined by back-titrating excess $\mathrm{NaOH}$ with $1.0 \mathrm{~mol} \mathrm{~L}^{-1} \mathrm{HCl}$ after addition of $\mathrm{BaCl}_{2}$ to precipitate carbonate (Anderson, 1982). Jars incubated with no soil were used to estimate background $\mathrm{CO}_{2}$ concentration and results were expressed as $\mathrm{mg} \mathrm{C} \mathrm{kg}^{-1}$ soil.

\section{Nitrogen Mineralization Over 24 Days}

Soils from the 3-d flush of $\mathrm{CO}_{2}$ were incubated for an additional $21 \mathrm{~d}$ to determine short-term potentially mineralizable N (Nmin_24), as suggested by Franzluebbers et al. (2000). The jars were opened two to three times a week to ensure sufficient oxygen. Soils were dried at $60^{\circ} \mathrm{C}$, and the amount of $\mathrm{NO}_{3}-\mathrm{N}$ and $\mathrm{NH}_{4}-\mathrm{N}$ mineralized determined as described above for the long-term incubation study. The amount of $\mathrm{N}$ mineralized was calculated by subtracting initial $\mathrm{NO}_{3}-\mathrm{N}$ and $\mathrm{NH}_{4}-\mathrm{N}$.

\section{Calcium Hypochlorite Oxidation}

Organic matter oxidized by addition of calcium hypochlorite $\left[\mathrm{Ca}(\mathrm{OCl})_{2}\right]$ to a soil-water infusion $(5 \mathrm{~g}$ soil $+5 \mathrm{~mL}$ of water) was measured as the change in pressure inside a sealed 120-mL serum bottle as described by Picone et al. (2002). We investigated this procedure because it is simple, low cost, and has been shown to be related to total organic matter content, potentially mineralizable $\mathrm{N}$, and the capacity of the soil to evolve $\mathrm{CO}_{2}$ (Picone et al., 2002).

\section{Statistical Analysis}

All statistical analyses were conducted using version 9.2 of SAS (SAS Institute Inc., 2008). Normality of data was assessed using the UNIVARIATE procedure. Values of $\mathrm{N}_{0}, \mathrm{~N}_{0}{ }^{*}, k$, and all $\mathrm{N}$ indices were log transformed to normalize the data for the remaining statistical procedures. Correlations among indices, and between indices and $\mathrm{N}_{0}, \mathrm{~N}_{0}{ }^{*}$, or $k$ were determined with the CORR procedure. Linear relationships between the indi- 
ces and $\mathrm{N}_{0}, \mathrm{~N}_{0}{ }^{*}$, or $k$ were evaluated using the ROBUSTREG procedure. The stepwise method of the REG procedure was used to determine the best combination of indices for predicting $\mathrm{N}_{0}$, $\mathrm{N}_{0}{ }^{*}$, or $k$. A significance level of $\alpha=0.05$ was used in all cases.

\section{RESULTS AND DISCUSSION}

Soil physical and chemical properties are presented in Table 3 and are typical representatives of the weathered soils of the 2 South. Soil textures ranged from sand to 2 clay, with most being loams. Soil $\mathrm{pH}$ ranged 3 from 4.8 in the 5 - to $15-\mathrm{cm}$ layer of the Cecil 3 soil to 8.0 for the 5 - to $15-\mathrm{cm}$ layer of the Austin soil (Table 3 ). Similar ranges in val- 3 ues were determined for C, N, POMC, and 4 POMN (Table 4). Maximum values of C, N, 4 POMC, and POMN were 44.9, 3.3, 22.4, 4 and $1.4 \mathrm{~g} \mathrm{~kg}^{-1}$, respectively, for the Austin 4 soil while minimum values of $3.6,0.2,1.1,5$ and $0.03 \mathrm{~g} \mathrm{~kg}^{-1}$, respectively, were deter- 5 mined for the Tifton soil (see Table 2 for 5 soil descriptions).

Broad ranges in values were also ob- 6 served for extractable or distillable N. 6 Maximum values for Cold_N, Hot_N, 6 Hyd_N, NaOH_N, and PB_N were 31.8, 6 35.4, 27.3, 453.5, and $59.9 \mathrm{mg} \mathrm{kg}^{-1}$, re- 7 spectively, while minimum values were $0.1,7$ $2.9,2.0,33.0$, and $7.0 \mathrm{mg} \mathrm{kg}^{-1}$, respectively. 7 Mean values for these methods were 4.1, 7 $10.6,8.1,155.5$, and $29.3 \mathrm{mg} \mathrm{kg}^{-1}$, respec- 8 tively. Comparing means among these meth- 8 ods indicates they identify different $\mathrm{N}$ pools 8 with a progression of Cold_ $N<$ Hot_N $N=8$ Hyd_N $<$ PB_N $<$ NaOH_N. The Cold_N 9 represents the inorganic $\mathrm{N}$ fraction, while the 9 Hot_N and Hyd_N includes easily decom- 9 posable organic matter while the PB_N and 9 $\mathrm{NaOH}$ _N (distilled $\mathrm{N}$ ) fractions are probably derived from these fractions along with other more resistant but hydrolyzable unidentified $\mathrm{N}$ fractions (Greenfield, 2001). Among these procedures, $\mathrm{NaOH} \_\mathrm{N}$ is the most aggressive representing on average $14 \%$ of TN, while Cold_N and Hyd_N represented only 0.4 and $0.7 \%$ of TN, respectively.

Correlation coefficients among methods were significant with several having $r$ values greater than 0.90 (Table 5). Biological methods (Ana_N, Nmin_24, and $\mathrm{Fl} \_\mathrm{CO}_{2}$ ) had stronger associations with $\mathrm{C}, \mathrm{N}$, POMC, and POMN than chemical methods. Correlations among chemical methods were similar to correlations between chemical and biological methods (Table 5). Biological methods generally had stronger associations with each other $(r=0.86$ to 0.91 ) than with the chemical methods ( $r=0.60$ to 0.94 ). Of the chemical methods, Hot_N and Hyd_N (estimated from the same procedure) had the strongest association with the biological methtion indices.
Table 3. Physical and chemical properties of soils used in evaluation of $\mathrm{N}$ mineraliza-

\begin{tabular}{|c|c|c|c|c|c|c|c|c|c|c|c|}
\hline ID & Soil series & s Tillaget & Depth & Sand & Silt & Clay & $\mathrm{pH}$ & $\mathbf{P}$ & K & $\mathrm{Ca}$ & $\mathrm{Mg}$ \\
\hline & & & $\mathrm{cm}$ & & - \% & . & & & & $\mathrm{g} \mathrm{ha}^{-1}$ & \\
\hline & Bama & $\mathrm{CT}$ & $0-5$ & 56 & 37 & 7 & 6.9 & 127 & 289 & 1680 & 361 \\
\hline & Bama & $\mathrm{CT}$ & 5-15 & 54 & 41 & 5 & 6.9 & 92 & 209 & 1565 & 352 \\
\hline & Bama & $\mathrm{NT}+\mathrm{SS}$ & $0-5$ & 56 & 40 & 5 & 6.7 & 140 & 244 & 2153 & 458 \\
\hline & Bama & $\mathrm{NT}+\mathrm{SS}$ & 5-15 & 55 & 35 & 10 & 6.8 & 45 & 191 & 1434 & 333 \\
\hline & Compass & CT & $0-5$ & 79 & 20 & 1 & 6.3 & 67 & 167 & 876 & 104 \\
\hline & Compass & CT & 5-15 & 79 & 20 & 0 & 6.4 & 45 & 96 & 863 & 89 \\
\hline & Compass & $\mathrm{NT}+\mathrm{SS}$ & $0-5$ & 80 & 19 & 0 & 6.5 & 59 & 116 & 1081 & 144 \\
\hline & Compass & $\mathrm{NT}+\mathrm{SS}$ & 5-15 & 82 & 18 & 0 & 5.8 & 64 & 70 & 603 & 65 \\
\hline & Tifton & $\mathrm{CT}$ & $0-5$ & 87 & 12 & 1 & 6.1 & 57 & 135 & 541 & 48 \\
\hline & Tifton & СТ & 5-15 & 85 & 12 & 3 & 5.5 & 42 & 77 & 268 & 19 \\
\hline & Tifton & ST & $0-5$ & 90 & 9 & 1 & 6.5 & 91 & 172 & 1201 & 98 \\
\hline & Tifton & ST & $5-15$ & 91 & 8 & 1 & 6.2 & 57 & 100 & 507 & 37 \\
\hline & Cecil & CT & $0-5$ & 73 & 24 & 3 & 5.9 & 337 & 290 & 1387 & 168 \\
\hline & Cecil & СТ & $5-15$ & 72 & 25 & 4 & 6.0 & 319 & 315 & 1497 & 176 \\
\hline & Cecil & NT & $0-5$ & 76 & 19 & 6 & 5.9 & 575 & 278 & 3056 & 298 \\
\hline & Cecil & NT & 5-15 & 75 & 21 & 4 & 5.7 & 112 & 163 & 590 & 88 \\
\hline & Cecil & СТ & $0-5$ & 70 & 24 & 5 & 5.0 & 74 & 163 & 500 & 71 \\
\hline & Cecil & CT & $5-15$ & 67 & 26 & 7 & 4.8 & 52 & 132 & 465 & 58 \\
\hline & Cecil & NT & $0-5$ & 75 & 21 & 4 & 5.6 & 99 & 191 & 2221 & 203 \\
\hline & Cecil & NT & 5-15 & 75 & 21 & 4 & 4.8 & 36 & 89 & 322 & 29 \\
\hline & Sharkey & CT & $0-5$ & 5 & 53 & 42 & 6.5 & 60 & 355 & 5426 & 1257 \\
\hline & Sharkey & СТ & $5-15$ & 4 & 52 & 44 & 6.4 & 51 & 363 & 5440 & 1277 \\
\hline & Sharkey & NT & $0-5$ & 5 & 54 & 41 & 6.4 & 48 & 445 & 4931 & 1131 \\
\hline & Sharkey & NT & 5-15 & 4 & 54 & 42 & 6.6 & 57 & 420 & 5468 & 1238 \\
\hline & Adco & СТ & $0-5$ & 8 & 78 & 14 & 7.3 & 137 & 209 & 4853 & 374 \\
\hline & Adco & СТ & $5-15$ & 6 & 79 & 15 & 6.7 & 32 & 128 & 3357 & 259 \\
\hline & Adco & NT & $0-5$ & 8 & 77 & 16 & 7.3 & 128 & 207 & 5727 & 400 \\
\hline & Adco & NT & 5-15 & 6 & 78 & 16 & 7.0 & 32 & 132 & 3877 & 300 \\
\hline & Norfolk & CT & $0-5$ & 73 & 25 & 2 & 6.4 & 24 & 307 & 861 & 158 \\
\hline & Norfolk & CT & $5-15$ & 73 & 25 & 2 & 6.3 & 19 & 153 & 861 & 130 \\
\hline & Norfolk & $\mathrm{NT}+\mathrm{SS}$ & $0-5$ & 76 & 23 & 1 & 6.9 & 106 & 249 & 3230 & 632 \\
\hline & Norfolk & $\mathrm{NT}+\mathrm{SS}$ & 5-15 & 75 & 23 & 1 & 6.7 & 72 & 102 & 967 & 150 \\
\hline & Lexington & $\mathrm{CT}$ & $0-5$ & 10 & 79 & 11 & 6.7 & 33 & 99 & 2891 & 199 \\
\hline & Lexington & CT & 5-15 & 7 & 79 & 14 & 6.5 & 32 & 106 & 2193 & 197 \\
\hline & Lexington & NT & $0-5$ & 12 & 78 & 11 & 7.0 & 37 & 161 & 8903 & 253 \\
\hline & Lexington & NT & 5-15 & 9 & 79 & 12 & 7.2 & 40 & 165 & 5015 & 299 \\
\hline & Pullman & NT & $0-5$ & 21 & 52 & 27 & 6.4 & 132 & 661 & 3277 & 620 \\
\hline & Pullman & NT & $5-15$ & 18 & 51 & 32 & 6.7 & 93 & 554 & 3652 & 652 \\
\hline & Pullman & SM & $0-5$ & 21 & 50 & 29 & 6.6 & 98 & 626 & 3676 & 661 \\
\hline & Pullman & SM & 5-15 & 19 & 49 & 31 & 6.6 & 76 & 440 & 3023 & 537 \\
\hline & Austin & SM & $0-5$ & 10 & 49 & 41 & 7.9 & 7 & 168 & 47544 & 130 \\
\hline & Austin & SM & 5-15 & 10 & 50 & 40 & 8.0 & 5 & 136 & 47544 & 112 \\
\hline & Austin & NP & $0-5$ & 8 & 45 & 46 & 7.7 & 10 & 257 & 47544 & 233 \\
\hline & Austin & NP & 5-15 & 7 & 41 & 53 & 7.8 & 9 & 150 & 47544 & 197 \\
\hline
\end{tabular}

† Tillage abbreviations as in Table 2 . 


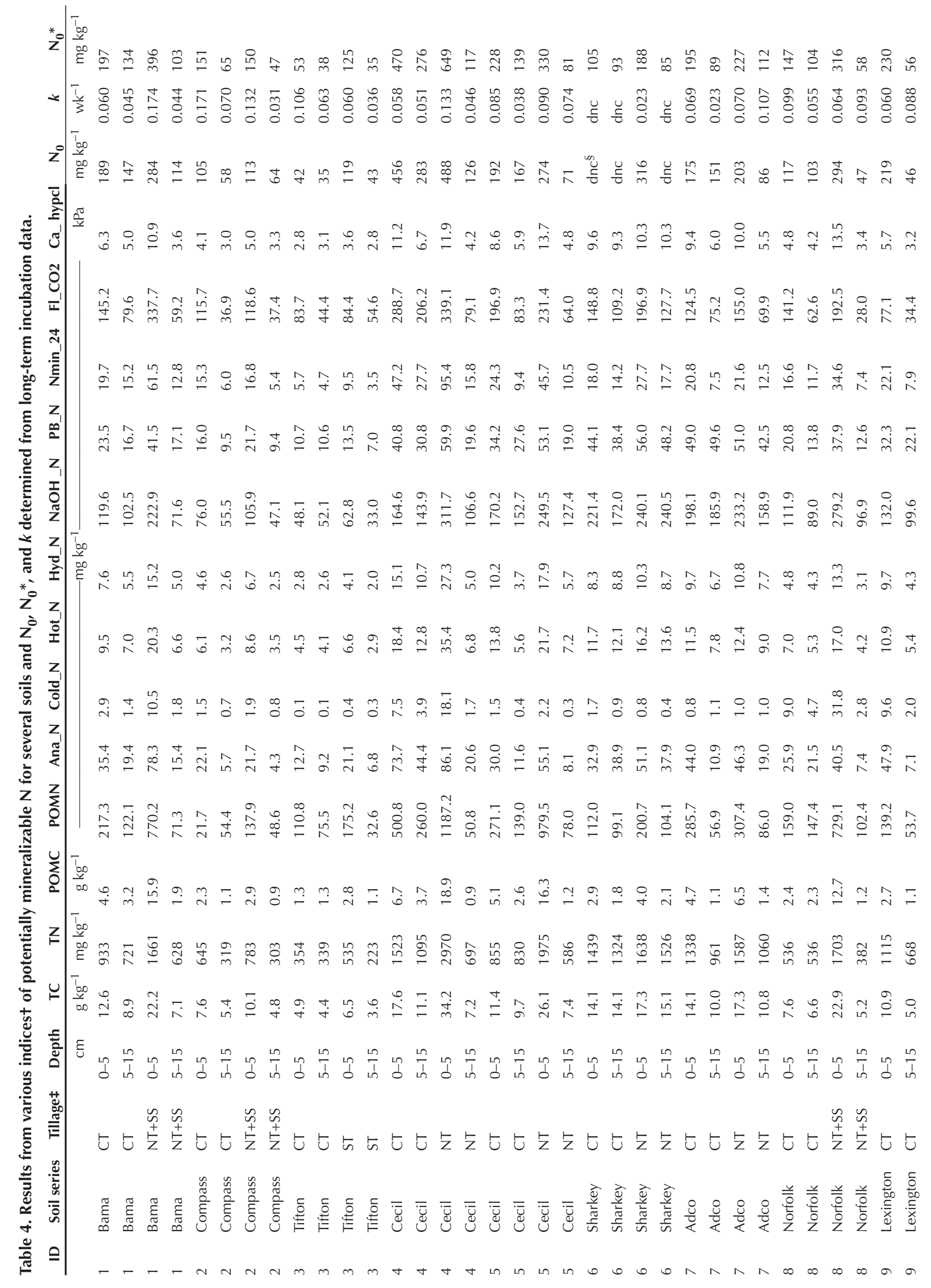




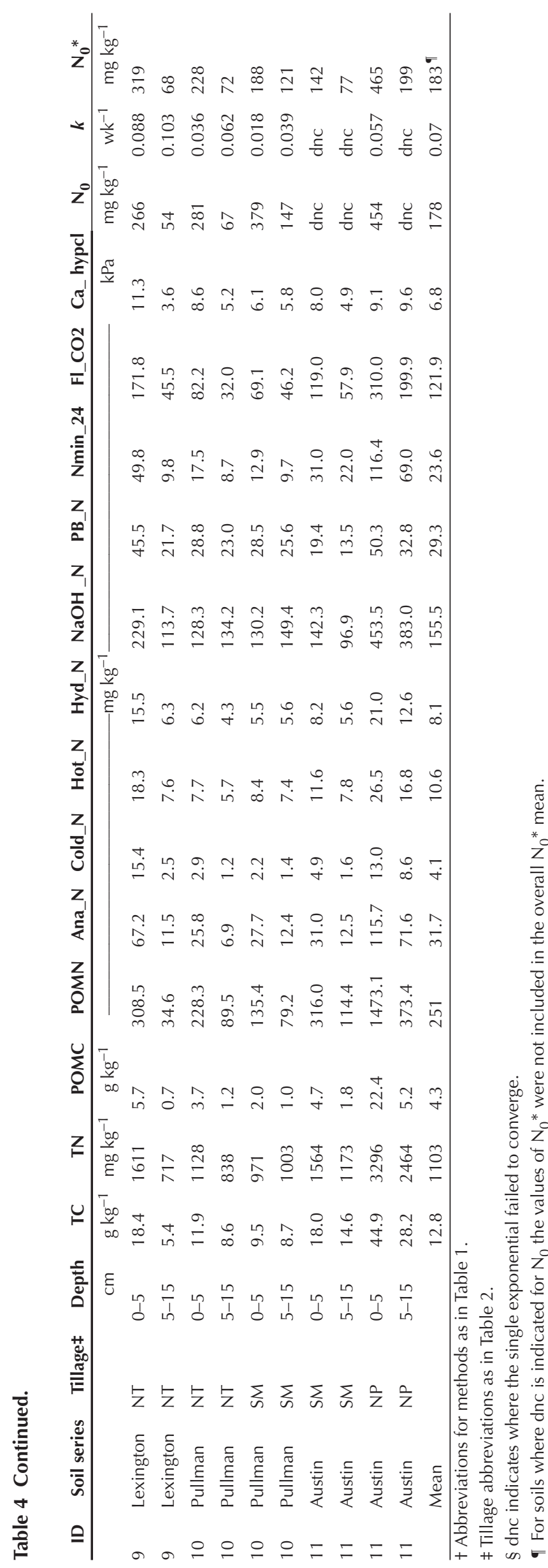

and for soil management effects (Bushong et al., 2007, 2008; Soon et al., 2007). It is a more standardized, simpler, and quicker procedure than the long-term aerobic incubation procedure. In our evaluations, Ana_N was strongly and positively correlated with Hot_N, Hyd_N, Nmin_24, and Fl_CO 2 . Soon et al. (2007) also found a strong correlation between Nmin_24 and Ana_N $r$ $=0.90)$. Several authors have suggested the $7-\mathrm{d}$ anaerobic incubation is the best biological indicator of potentially available $\mathrm{N}$ (Bushong et al., 2007, 2008; Soon et al., 2007).

Values of $\mathrm{N}_{0}$ determined with the single exponential equation for each soil-tillage-depth combination ranged from $35 \mathrm{mg} \mathrm{N} \mathrm{kg}^{-1}$ soil for the 5 - to $15-\mathrm{cm}$ depth of the conventionally tilled Tifton soil to $488 \mathrm{mg} \mathrm{N} \mathrm{kg}^{-1}$ soil for the 5 - to $15-\mathrm{cm}$ depth of the no-till Cecil soil having a long history of poultry litter application (Table 4). Values for $\mathrm{N}_{0}$ and $k$ could not be determined for three out of the four treatments of the Sharkey and Austin soils because the exponential equation did not fit the observations. Cumulative mineralized $\mathrm{N}$ declined later in the incubation for treatments that failed to converge which indicated possible $\mathrm{N}$ losses due to denitrification. The range of values observed for $\mathrm{N}_{0}$ is similar to other reports in the literature [Curtin and Wen, 1999 (71 to $630 \mathrm{mg} \mathrm{kg}^{-1}$ ); Jalil et al., 1996 (71 to $278 \mathrm{mg} \mathrm{kg}^{-1}$ )]. Sharifi et al. (2007) recently reported a range of 54 to $197 \mathrm{mg} \mathrm{N} \mathrm{kg}^{-1}$ soil for 153 samples from 17 field studies in New Brunswick, Quebec, Manitoba, and Saskatchewan, Canada, and Maine, USA. The average value for $\mathrm{N}_{0}$ for our soils was $178 \mathrm{mg} \mathrm{N} \mathrm{kg}^{-1}$ soil. Values of $k$ ranged from $0.018 \mathrm{wk}^{-1}$ for the 5 - to $15-\mathrm{cm}$ depth of the Pullman soil in stubble mulch tillage to $0.174 \mathrm{wk}^{-1}$ for the 0 - to $5-\mathrm{cm}$ depth of the Bama soil in no-till with non-inversion deep tillage. The average $k$ for all soils was $0.070 \mathrm{wk}^{-1}$. This is similar to the average $k$ of $0.054 \mathrm{wk}^{-1}$ reported by Stanford and Smith (1972) for several U.S. soils, $0.067 \mathrm{wk}^{-1}$ for 42 soils from the Saskatchewan province reported by Jalil et al. (1996) and $0.080 \mathrm{wk}^{-1}$ reported by Curtin and Wen (1999). Other authors have observed that $k$ values exhibited a wide range over soils (Juma et al., 1984; Paustian and Bonde 1987; Dendooven et al., 1995; Wang et al., 2003; Sharifi et al., 2007).

Using the approach of Wang et al. (2003) to determine $\mathrm{N}_{0}{ }^{*}$ with a fixed $k\left(0.054 \mathrm{wk}^{-1}\right)$ produced slightly greater values compared with $\mathrm{N}_{0}$. The average value of $\mathrm{N}_{0}{ }^{*}$ was $183 \mathrm{mg} \mathrm{N} \mathrm{kg}^{-1}$ soil, and ranged from 35 to $649 \mathrm{mg} \mathrm{N} \mathrm{kg}^{-1}$ soil. Within a location, the values of $\mathrm{N}_{0}$ and $\mathrm{N}_{0}{ }^{*}$ were very close. In general, greater amounts of potentially mineralizable $\mathrm{N}$ were found in minimum tillage systems compared with conventional tillage systems, and for surface soil compared with subsurface soil. The contrast between surface and subsurface soil was usually greater with $\mathrm{N}_{0}{ }^{*}$ compared with $\mathrm{N}_{0}$. One consequence of fitting $\mathrm{N}_{0}{ }^{*}$ with a fixed $k$ is that it allowed the exponential model to converge for all treatments including those from the Austin and Sharkey soils (Table 4). Although the fit of the model was not good in these cases, the resulting estimates of $\mathrm{N}_{0}{ }^{*}$ were consistent with results for the other soils as to differences between management and soil depth. Wang et al. (2003) cautioned that $\mathrm{N}_{0}{ }^{*}$ estimated with a fixed $k$ does not represent a discrete and homogeneous pool of similar chemical forms of organic $\mathrm{N}$, but they suggest it provides a reliable benchmark to allow comparison of $\mathrm{N}$ mineralization capacity between different soils. 
Table 5. Pearson correlation coefficients $(r)$ indicating association between laboratory methods.

\begin{tabular}{|c|c|c|c|c|c|c|c|c|c|c|c|c|}
\hline & $\mathrm{Ct}$ & $\mathbf{N}$ & POMC & POMN & Cold_N & Hot_N & Hyd_N & $\mathbf{N a O H} \_\mathrm{N}$ & PB_N & Ana_N & Nmin_24 & FI_CO2 \\
\hline$N$ & $0.959^{\ddagger}$ & & & & & & & & & & & \\
\hline POMC & 0.857 & 0.750 & & & & & & & & & & \\
\hline POMN & 0.844 & 0.748 & 0.932 & & & & & & & & & \\
\hline Cold_N & 0.609 & 0.598 & 0.604 & 0.591 & & & & & & & & \\
\hline Hot_N & 0.936 & 0.937 & 0.836 & 0.822 & 0.622 & & & & & & & \\
\hline Hyd_N & 0.925 & 0.933 & 0.822 & 0.805 & 0.665 & 0.988 & & & & & & \\
\hline $\mathrm{NaOH} \_\mathrm{N}$ & 0.899 & 0.937 & 0.681 & 0.709 & 0.572 & 0.888 & 0.888 & & & & & \\
\hline PB_N & 0.807 & 0.882 & 0.617 & 0.616 & 0.448 & 0.865 & 0.873 & 0.918 & & & & \\
\hline Ana_N & 0.862 & 0.841 & 0.848 & 0.799 & 0.604 & 0.913 & 0.894 & 0.764 & 0.755 & & & \\
\hline Nmin_24 & 0.930 & 0.890 & 0.876 & 0.845 & 0.744 & 0.935 & 0.931 & 0.815 & 0.710 & 0.907 & & \\
\hline Fl_CO2 & 0.826 & 0.749 & 0.876 & 0.795 & 0.504 & 0.876 & 0.846 & 0.699 & 0.694 & 0.912 & 0.863 & \\
\hline Ca_hypcl & 0.888 & 0.858 & 0.812 & 0.795 & 0.515 & 0.891 & 0.877 & 0.845 & 0.836 & 0.810 & 0.801 & 0.807 \\
\hline
\end{tabular}

† Abbreviations as in Table 1.

₹ All correlations significant at $P<0.001$ except for PB_N vs. Cold_N, which was significant at $P=0.002$.

Correlations between $\mathrm{N}_{0}$ and the $\mathrm{N}$ mineralization methods were variable ranging from 0.615 to 0.887 (Fig. 1). Figure 1 shows that the association of $\mathrm{N}_{0}$ with several indices is good for most soils. The strongest correlations with $\mathrm{N}_{0}$ were with total C and N, Ana_N, Hot_N, and Nmin_24. Total C and N can be determined in a relatively short period of time, while Hot_N and Hyd_N require a 4-h incubation. Longer periods of time are required to determine Ana_N and Nmin_24, but they may be more reliable (Table 5 and Fig. 1B). Soon et al. (2007) reported lower coefficients of variation for Ana_N and Nmin_24 compared with other methods. Weighted least square regressions indicated these methods explained 60 to $65 \%$ of the variation in $\mathrm{N}_{0}$ (Table 6). Somewhat lower correlations and fits of regressions were found for the other $\mathrm{N}$ indices; however, most had correlations above $r=0.75$ (Fig. 1) and weighted least square regression coefficients with $r^{2}>0.50$ (Table 6).

Gianello and Bremner (1986a, 1986b, 1988) proposed Hot_N and PB_N as two methods to predict $\mathrm{N}_{0}$. Jalil et al. (1996) reported $r^{2}$ values of $0.54,0.48,0.78$, and 0.73 for linear regressions of $\mathrm{N}_{0}$ with organic $\mathrm{N}$, Hot_N, Hyd_N, and PB_N, respectively. Clay and Malzer (1993) found that PB_N more accurately reflected changes in mineralizable $\mathrm{N}$ and $\mathrm{N}$ availability to soybean (Glycine max L. Merr.) over time compared with Hot_N. Sharifi et al. (2007) found the correlations for PB_N and Hot_N with $\mathrm{N}_{0}$ were not significant, which was similar to the lower correlation found by Curtin and Wen (1999). Curtin and Wen (1999) also reported that Hot_N was poorly correlated with $\mathrm{N}_{0}(r=0.36, P<0.01)$, but it was reasonably well related to $\mathrm{N}$ mineralized in the first 2 wk of incubation $(r=0.80, P<0.001)$. Our results for Hot_N and PB_N indicated a much stronger relationship with $\mathrm{N}_{0}$ compared with the results of Sharifi et al. (2007) and Curtin and Wen (1999). Unlike Jalil et al. (1996) and Curtin and Wen (1999), who found improved predictions of $\mathrm{N}_{0}$ with Hyd_N (not corrected for the initial $\mathrm{NH}_{4}-\mathrm{N}$ concentration), our results indicate that Hot_N and Hyd_N produce similar predictions of $\mathrm{N}_{0}$ (Table 6). The strong association between $\mathrm{N}_{0}$ and Nmin_24 supports other research indicating that short term aerobic incubations may be useful for indicating $\mathrm{N}$ availability in soils (Franzluebbers, 1999; Franzluebbers et al., 2000; Soon et al., 2007). Data from Stanford and Smith (1972), Smith et al. (1994), and Jalil et al. (1996) indicate that short-term $(14 \mathrm{~d}) \mathrm{N}$ mineralization is highly related $\left(r^{2}=0.80\right.$ $\pm 0.05)$ to net $\mathrm{N}$ mineralization during 168 to $210 \mathrm{~d}$. Soon et al. (2007) demonstrated that Nmin_24 and Ana_N were more sensitive to tillage, liming, and crop sequences compared to Hot_N or Hyd_N, especially when using 5-cm deep soils.

Correlations between $k$ and the $\mathrm{N}$ indices were poor, and only significant for $\mathrm{C}$ and $\mathrm{N}$ (Fig. 1). Linear regression results were similar to the correlation results in that none of the indices were good predictors of $k$ using linear regression (Table 6). In contrast to our results, Curtin and Wen (1999) found significant $(P<0.001)$ positive relationships between $k$ and Hot_N $\left(r^{2}=\right.$ $0.56)$ and PB_N $\left(r^{2}=0.37, P<0.001\right)$. Other authors have reported poor association between various indices and $k$. It is not surprising that $k$ would be poorly correlated with any of the indices since these indices predominantly measure various fractions of the $\mathrm{N}$ pool and $k$ is an indication of the susceptibility of these pools to microbial activity. Estimation of $k$ is problematic because it is very sensitive to variation in the dataset. In a Monte Carlo simulation, even small (1-2\%) amounts of random variation have been shown to result in greater variation in estimates of $k$ even when the underlying function was in fact exponential (Fisher et al., 1989). Use of a single exponential model in field studies is a simplification, and the logistics of determining data for each point within 1 or $2 \%$ generally prevents estimation of $k$ with high precision (Schomberg and Cabrera, 2001; Schomberg et al., 2006). Even with this caveat, it appears that $k$ may be less variable compared with $\mathrm{N}_{0}$ across a wide range of soils as indicated by Stanford and Smith (1972) and reflected in our data and the data of Curtin and Wen (1999) and Jalil et al. (1996). Wang et al. (2003) showed that changes in $\mathrm{N}_{0}$ and $k$ were often inversely related, and were a function of the nonlinear iterative fitting process as well as the length of incubation. These factors led to their evaluation of using a standard $k$ for determining $\mathrm{N}_{0}$, which more accurately reflected soil conditions compared with simultaneous fitting $\mathrm{N}_{0}$ and $k$. If $k$ determined under standard conditions falls within a narrow range for most soils as indicated by many papers in the literature, then there would be little reason to expect it to be correlated to the various indices, and the use of a standard $k$ could help in promoting the estimation of potential $\mathrm{N}$ mineralization by soil testing laboratories.

Correlations between $\mathrm{N}_{0}{ }^{*}$ and the $\mathrm{N}$ mineralization indices were better than those between $\mathrm{N}_{0}$ and the indices (Fig. 1). Correlations ranged from 0.71 to 0.95 with the best correlations 
A

TC

TN POMC

POMN

Cold_N

Hot_N

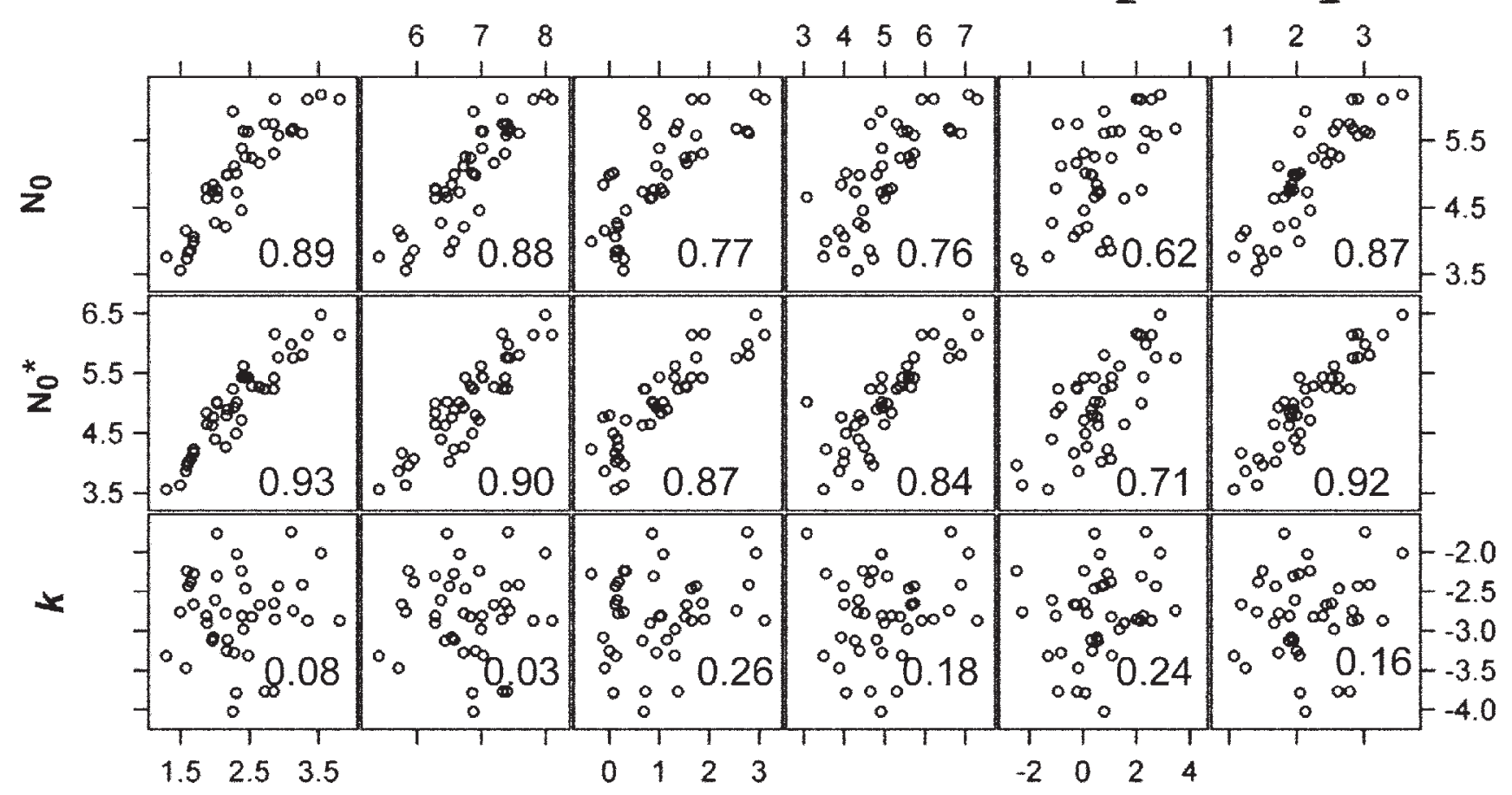

B

$\mathrm{NaOH}+\mathrm{N} \quad \mathrm{PB} \_\mathrm{N}$

Ana_N

Nmin_24

FI_CO2

Ca_hypd

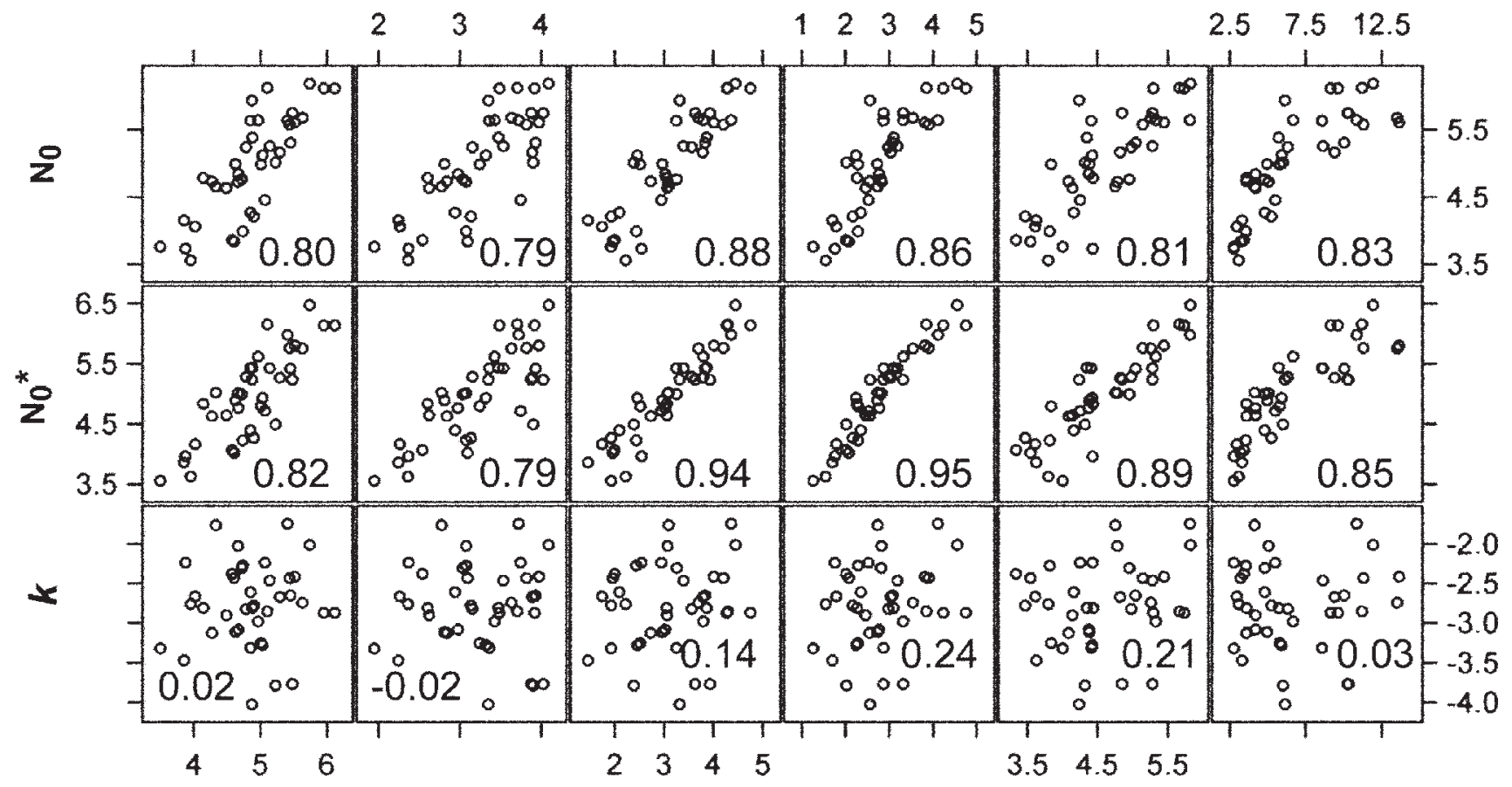

Fig. 1. Scatter plots indicating associations for laboratory $N$ indicest with $N_{0}, N_{0}{ }^{*}$, and $k$. Hyd_N is not included in the plot matrix because it

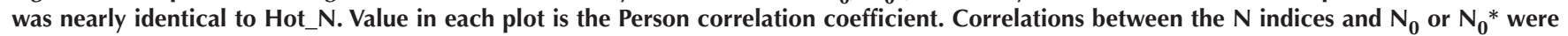
significant at $\boldsymbol{P}<0.001$ while correlations between the $\mathrm{N}$ indices and $k$ were not significant at $\boldsymbol{P}<0.05$. Abbreviations as in Table 1. Units for $\mathrm{C}$ and POMC are $\log \left(\mathrm{g} \mathrm{kg}^{-1}\right)$. Units for N, POMN, Cold_N, Hot_N, NaOH_N, PB_N, Ana_N, Nmin_24, FI_CO2, $\mathrm{N}_{0}$ and $\mathrm{N}_{0}{ }^{*}$ are log $\left(\mathrm{mg}\right.$ kg $\left.{ }^{-1}\right)$. Unit for $\mathrm{Ca} \_$hypcl is $\log (\mathrm{kPa})$ and for $k$ is $\log \left(w^{-1}\right)$.

being with Nmin_24, Ana_N, total C, and Hot_N (same as with $\mathrm{N}_{0}$ ). Examining Fig. 1 shows the closer alignment of data along the 1 to 1 line for $\mathrm{N}_{0}{ }^{*}$ compared with $\mathrm{N}_{0}$. Prediction of $\mathrm{N}_{0}{ }^{*}$ with the $\mathrm{N}$ indices using linear regression resulted in coefficients of determination ranging from 0.46 to 0.82 (Table 6).
The best predictor of $\mathrm{N}_{0}{ }^{*}$ was Nmin_24, which described $82 \%$ of the variation in $\mathrm{N}_{0}{ }^{*}$. Other indices resulting in good linear regressions with $\mathrm{N}_{0}{ }^{*}$ were Ana_N, total C, and Hot_N. Cold_N was the poorest estimator of $\mathrm{N}_{0}{ }^{*}$ with an $r^{2}=0.46$. 
Table 6. Equationst for predicting $\mathrm{N}_{0}, \mathrm{~N}_{0}{ }^{*}$, and $k$ from $\mathrm{N}$ indices.

\begin{tabular}{|c|c|c|c|c|c|c|}
\hline & $\mathbf{N}$ index & Intercept & Standard error $\ddagger$ & Slope & Standard error & WLS $r^{2}$ \\
\hline \multirow[t]{13}{*}{$\overline{\mathrm{N}_{0} \text { ฯ }}$} & $\mathrm{TC}$ & 2.36 & 0.23 & 1.12 & 0.09 & 0.65 \\
\hline & $\mathrm{TN}$ & -2.15 & 0.63 & 1.05 & 0.09 & 0.64 \\
\hline & POMC & 4.33 & 0.12 & 0.64 & 0.08 & 0.52 \\
\hline & POMN & 2.11 & 0.41 & 0.57 & 0.08 & 0.50 \\
\hline & Cold_N & 4.77 & 0.11 & 0.34 & 0.07 & 0.35 \\
\hline & Hot_N & 2.58 & 0.23 & 1.10 & 0.10 & 0.62 \\
\hline & Hyd_N & 3.05 & 0.21 & 1.01 & 0.10 & 0.60 \\
\hline & $\mathrm{NaOH} \_\mathrm{N}$ & -0.02 & 0.60 & 1.03 & 0.12 & 0.55 \\
\hline & PB_N & 1.60 & 0.43 & 1.05 & 0.13 & 0.54 \\
\hline & Ana_N & 2.54 & 0.22 & 0.78 & 0.07 & 0.63 \\
\hline & Nmin_24 & 2.71 & 0.20 & 0.80 & 0.07 & 0.62 \\
\hline & Fl_CO2 & 0.78 & 0.43 & 0.91 & 0.09 & 0.58 \\
\hline & Ca_hypcl & 3.69 & 0.16 & 0.19 & 0.02 & 0.57 \\
\hline \multirow[t]{13}{*}{$\mathrm{N}_{0}{ }^{*}$} & C & 2.32 & 0.18 & 1.14 & 0.08 & 0.75 \\
\hline & $\mathrm{N}$ & -2.12 & 0.57 & 1.05 & 0.08 & 0.69 \\
\hline & POMC & 4.27 & 0.09 & 0.70 & 0.06 & 0.65 \\
\hline & POMN & 1.52 & 0.31 & 0.69 & 0.06 & 0.64 \\
\hline & Cold_N & 4.76 & 0.09 & 0.39 & 0.06 & 0.46 \\
\hline & Hot_N & 2.49 & 0.17 & 1.15 & 0.08 & 0.77 \\
\hline & Hyd_N & 2.97 & 0.14 & 1.07 & 0.07 & 0.65 \\
\hline & $\mathrm{NaOH} \_\mathrm{N}$ & 0.02 & 0.57 & 1.02 & 0.12 & 0.60 \\
\hline & PB_N & 1.71 & 0.42 & 1.01 & 0.13 & 0.57 \\
\hline & Ana_N & 2.45 & 0.16 & 0.81 & 0.05 & 0.75 \\
\hline & Nmin_24 & 2.60 & 0.13 & 0.85 & 0.04 & 0.82 \\
\hline & Fl_CO2 & 0.88 & 0.31 & 0.91 & 0.07 & 0.64 \\
\hline & Ca_hypcl & 3.70 & 0.15 & 0.19 & 0.02 & 0.66 \\
\hline \multirow[t]{13}{*}{$k$} & $\mathrm{TC}$ & -2.96 & 0.35 & 0.07 & 0.15 & 0.01 \\
\hline & $\mathrm{TN}$ & -2.98 & 0.94 & 0.03 & 0.14 & 0.00 \\
\hline & POMC & -2.95 & 0.13 & 0.15 & 0.09 & 0.05 \\
\hline & POMN & -3.27 & 0.44 & 0.09 & 0.09 & 0.03 \\
\hline & Cold_N & -2.85 & 0.09 & 0.10 & 0.06 & 0.04 \\
\hline & Hot_N & -3.11 & 0.33 & 0.14 & 0.15 & 0.03 \\
\hline & Hyd_N & -3.11 & 0.27 & 0.16 & 0.14 & 0.04 \\
\hline & $\mathrm{NaOH} \_\mathrm{N}$ & -2.87 & 0.72 & 0.01 & 0.15 & 0.00 \\
\hline & PB_N & -2.74 & 0.50 & -0.02 & 0.15 & 0.00 \\
\hline & Ana_N & -3.08 & 0.33 & 0.09 & 0.10 & 0.02 \\
\hline & Nmin_24 & -3.23 & 0.30 & 0.15 & 0.10 & 0.04 \\
\hline & Fl_CO2 & -3.53 & 0.57 & 0.16 & 0.12 & 0.03 \\
\hline & Ca_hypcl & -2.83 & 0.20 & 0.01 & 0.03 & 0.00 \\
\hline
\end{tabular}

+ Equations are $Y=$ Intercept + slope $(x)$ where $x$ is the measured $N$ index, and the intercept and slope were estimated by regression.

₹ Std Error is the standard error of the estimate.

$\S$ WLS $r^{2}$ is a weighted least squares estimate of $r^{2}$ from ROBUSTREG adjusted for outliers.

I All slopes and intercepts for predicting $\mathrm{N}_{0}$ and $\mathrm{N}_{0}{ }^{*}$ were significant at $P<0.001$. All intercepts for predicting $k$ were significant at $P<0.001$. Slopes for predicting $k$ from $N$, Hot_N, Hyd_N, Ana_N, and Nmin_24 were significant at $P<0.05$. All other slopes for $k$ were not significant.

Gallagher and Bartholomew (1964) found that predictions of $\mathrm{N}$ availability were improved when $\mathrm{N}$ test methods and soil properties were combined in multiple regressions. We used the stepwise selection method in the REG procedure to select the best combination of $\mathrm{N}$ indices for predicting $\mathrm{N}_{0}, \mathrm{~N}_{0}{ }^{*}$, and $k$. This purely empirical approach does not restrict the resulting equations to any hierarchical combination of methods based on organic matter fractions. The results may therefore not have a simple biological basis for interpretation, but could still be useful in establishing laboratory procedures for $\mathrm{N}$ recommendations.
The best combination of methods to estimate $\mathrm{N}_{0}$ was TN and Fl_CO2 (Table 7). Total $\mathrm{N}$ represents the total pool of $\mathrm{N}$ in the soil, and contains the mineralizable organic $\mathrm{N}$ as well as the more recalcitrant fraction of organic N while Fl_CO2 has been related to microbial biomass and mineralizable $\mathrm{C}$ and $\mathrm{N}$ in soils under different environments (Franzluebbers et al., 2000, 2001). The $\mathrm{CO}_{2}$ released in the Fl_CO2 procedure reflects both (i) microbial population dynamics, [growth in response to release of metabolites due to drying and osmotic shock following rewetting (Jenkinson, 1966, Sorensen, 1974, Kieft et al., 1987)], and (ii) the steady-state rate of C mineralization reflecting the mineralizability of organic matter. Measurement of Fl_CO2 is relatively fast (i.e., $0-3 \mathrm{~d}$ ) and sensitive, since 8 to 12 times more $\mathrm{C}$ than $\mathrm{N}$ is mineralized from soil organic matter.

The stepwise regression procedure identified a larger group of indices for prediction of $\mathrm{N}_{0}{ }^{*}$ compared to $\mathrm{N}_{0}$ (Table 7). The group included TN, Cold_N, NaOH_N, and Fl_CO2, and had an $R^{2}$ of 0.94 . Total $\bar{N}$ and $\mathrm{Fl} \_\mathrm{CO} 2$ were indices selected for prediction of $\mathrm{N}_{0}$. Addition of Cold_N and $\mathrm{NaOH}$ _N produces an interesting set of predictors. Cold_N is the mineral $\mathrm{N}$ pool initially present, and readily available to microorganisms on rewetting of the soil while $\mathrm{NaOH} \_\mathrm{N}$ measures the most chemically resistant but hydrolyzable $\mathrm{N}$ pool. On average $\mathrm{NaOH} \mathrm{N}$ represented $14 \%$ of TN, while Cold_N represented only $0.4 \%$ of $\mathrm{TN}$ in these soils. Wang and $\mathrm{Li}$ (1991) reported that predictions of plant $\mathrm{N}$ uptake in two pot experiments were significantly improved with inclusion of initial $\mathrm{NO}_{3}-\mathrm{N}$ with $\mathrm{NaOH}$-hydrolyzable $\mathrm{N}$ in regression equations (cited in Wang et al., 2001). Moreover, the correlation coefficients for $\mathrm{NaOH}$-hydrolyzable $\mathrm{N}$ plus mineral $\mathrm{N}$ were much greater than those for the initial $\left(\mathrm{NH}_{4}+\mathrm{NO}_{3}\right)-\mathrm{N}$ or TN (including $\left.\mathrm{NO}_{3}-\mathrm{N}\right)$. Wang et al. (2001) concluded that a test that integrates initial mineral $\mathrm{N}$ and $\mathrm{NaOH}$ hydrolyzable organic $\mathrm{N}$ would be a better index than TN (including mineral $\mathrm{N}$ ). With a multiple correlation coefficient of 0.94 , the equation for $\mathrm{N}_{0}{ }^{*}$ could be useful in estimating the size of the potentially mineralizable $\mathrm{N}$ pool for various soils particularly when modeling $\mathrm{N}$ cycling. Three of the four indices used in this equation are relatively fast to determine $(<1 \mathrm{~d})$ and Fl_CO 2 takes only $3 \mathrm{~d}$, which is much faster than a long-term incubation. These methods can also be determined using inexpensive equipment present in most laboratories (if TN is determined via Kjeldahl).

Prediction of $k$ with a combination of $\mathrm{N}$ indices proved to be elusive (Table 7 ). The equation for the selected group of indices had a relatively low $R^{2}(0.36)$ indicating poor prediction value. This result was not unexpected, as noted above, due to the potential for $k$ to be a characteristic mainly changing in response 
Table 7. Multiple indices equationst for predicting $\mathrm{N}_{0}, \mathrm{~N}_{0} *$, and $k$.

\begin{tabular}{|c|c|c|c|c|c|c|c|c|c|}
\hline \multirow{2}{*}{$\begin{array}{l}\text { Dependent } \\
\mathrm{N}_{0}\end{array}$} & \multirow{2}{*}{$\frac{\text { Variable }}{\text { Intercept }}$} & \multirow{2}{*}{$\begin{array}{c}\text { Parameter estimate } \\
-1.655\end{array}$} & \multirow{2}{*}{$\begin{array}{c}\text { Standard error } \\
0.509\end{array}$} & \multirow{2}{*}{$\frac{\operatorname{Pr}>|\mathbf{t}|}{0.0025}$} & \multicolumn{2}{|c|}{ 95\% Confidence limits } & \multirow{2}{*}{$\begin{array}{l}\text { RMSE } \\
0.288\end{array}$} & \multirow{2}{*}{$\frac{\text { Model } \boldsymbol{R}^{\mathbf{2}}}{0.86}$} & \multirow{2}{*}{$\frac{\text { Model Adj } \boldsymbol{R}^{\mathbf{2}}}{0.85}$} \\
\hline & & & & & -2.686 & -0.623 & & & \\
\hline \multirow{5}{*}{$\mathrm{N}_{0} *$} & $\mathrm{TN}$ & 0.682 & 0.114 & 0.0001 & 0.452 & 0.913 & & & \\
\hline & FI_CO2 & 0.432 & 0.104 & 0.0002 & 0.221 & 0.642 & & & \\
\hline & Intercept & -0.930 & 0.444 & 0.0436 & -1.831 & -0.028 & 0.185 & 0.94 & 0.94 \\
\hline & $\mathrm{TN}$ & 0.820 & 0.178 & 0.0001 & 0.459 & 1.181 & & & \\
\hline & Cold_N & 0.128 & 0.028 & 0.0001 & 0.072 & 0.185 & & & \\
\hline \multirow{5}{*}{ k } & $\mathrm{NaOH} \_\mathrm{N}$ & -0.336 & 0.167 & 0.0524 & -0.676 & 0.004 & & & \\
\hline & Fl_CO2 & 0.421 & 0.071 & 0.0001 & 0.277 & 0.564 & & & \\
\hline & Intercept & -3.563 & 0.390 & $<.0001$ & -4.356 & -2.771 & 0.408 & 0.36 & 0.30 \\
\hline & $\mathrm{TC}$ & -1.380 & 0.373 & 0.0008 & -2.139 & -0.622 & & & \\
\hline & POMN & 0.500 & 0.148 & 0.0019 & 0.199 & 0.802 & & & \\
\hline
\end{tabular}

+ Equations are constructed in the form $y=\beta_{0}+x 1 \beta_{1}+x 2 \beta_{2}+x 3 \beta_{3}+x 4 \beta_{4}$ where $\beta_{0}$ is the intercept, $\beta_{1}, \beta_{2}, \beta_{3}$, and $\beta_{4}$ are the parameter estimates and $\mathrm{x} 1, \mathrm{x} 2, \mathrm{x} 3$, and $\mathrm{x} 4$ are the measured $\mathrm{N}$ indices.

to physical influences and sensitivity in the fitting process. Many other authors have shown that it is difficult to identify a compositional factor that is predictive of $\mathrm{k}$, which is why Wang et al. (2003) advocate use of a standardized $k$. Use of a standardized $k$ that is modified due to climatic influences (temperature and water), as in many models, appears to be a logical approach for estimating $\mathrm{N}$ mineralization in most soils (Stanford and Smith, 1976; Campbell et al., 1997; Wang et al., 2003).

\section{SUMMARY AND CONCLUSIONS}

Our results indicate that a combination of laboratory methods can be useful for predicting potentially mineralizable $\mathrm{N}$ for a range of soils from the South, USA. The results should be applicable to other regions; however, combinations of indices may be slightly different due to types of clays and organic matter present in soils from other regions. We observed strong relationships between $\mathrm{N}_{0}$ and the $\mathrm{N}$ indices total C and N, Ana_N, Nmin_24, Hot_N, and Hyd_N. Of these indices total C and N, Hot_N and Hyd_N are easy and quick to determine, while Ana_N and Nmin_24 require more time, but proved to have stronger relationships with $\mathrm{N}_{0}$. Using a fixed value of $k$ in estimating $\mathrm{N}_{0}{ }^{*}$ improved the fit of relationships between the $\mathrm{N}$ indices and $\mathrm{N}_{0}{ }^{*}$. Combining indices in multiple regressions improved prediction of $\mathrm{N}_{0}$ or $\mathrm{N}_{0}{ }^{*}$ with the best equations having strong predictive potential $\left(R^{2}=0.86\right.$ and 0.94 , respectively). Combining TN and Fl_CO2 to predict $\mathrm{N}_{0}$ and $\mathrm{N}_{0}{ }^{*}$ relies on relatively simple methods, which are a logical combination of indices defining available substrate and microbial biomass. This particular combination could be easily adopted for predicting potential $\mathrm{N}$ availability over a range of soils and management conditions by soil testing laboratories and for modeling.

\section{ACKNOWLEDGMENTS}

This research was supported in part through the LABEX-USA program, a cooperative effort of USDA's Agricultural Research Service (ARS) and the Brazilian Agricultural Research Corporation (EMBRAPA). We are indebted to Dr. Pedro Arraes, LABEX Coordinator during the project and Ms. Gretchen Flanley from the ARS Office of International Research Programs for support throughout the project. We thank Robin Woodroof, Nathan Tyson, Robert Martin, Anthony Dillard, Steven Knapp, Alan Franzluebbers, Stephen Norris, Stephanie Steed, Juan Rodriguez, and John Rema for their assistance in many activities and analyses, and to the numerous support personnel who dedicated many hours to maintenance of the research sites used in this study.

\section{REFERENCES}

Anderson, J.P.E. 1982. Soil respiration. p. 831-871. In A.L. Page et al (ed.) Methods of soil analysis. Part 2. Agron. Monogr. No. 9. ASA and SSSA, Madison, WI.

Balkcom, K.S., A.M. Blackmer, D.J. Hansen, T.F. Morris, and A.P. Mallanario. 2003. Testing soils and cornstalks to evaluate nitrogen management on the watershed scale. J. Environ. Qual. 32:1015-1024.

Bremner, J.M. 1965. Total nitrogen. p. 1149-1178. In C.A. Black et al (ed.) Methods of soil analysis. Part 2. 1st ed. ASA, Madison, WI.

Bremner, J.M. 1996. Nitrogen-total. p. 1085-1121. In D.L. Sparks et al (ed.) Methods of soil analysis. Part 3. SSSA Book Ser. 5. ASA and SSSA, Madison, WI.

Bundy, L.G., and J.J. Meisinger. 1994. Nitrogen availability indices. p. 951984. In R.W. Weaver et al (ed.) Methods of soil analysis. Part 2. SSSA Book Ser. 5. ASA and SSSA, Madison, WI.

Bushong, J.T., R.J. Norman, W.J. Ross, N.A. Slaton, C.E. Wilson, Jr., and E.E. Gbur, Jr. 2007. Evaluation of several indices of potentially mineralizable soil nitrogen. Commun. Soil Sci. Plant Anal. 38:2799-2813.

Bushong, J.T., T.L. Roberts, W.J. Ross, R.J. Norman, N.A. Slaton, and C.E. Wilson, Jr. 2008. Evaluation of distillation and diffusion techniques for estimating hydrolyzable amino sugar-nitrogen as a means of predicting nitrogen mineralization. Soil Sci. Soc. Am. J. 72:992-999.

Campbell, C.A., Y.W. Jame, A. Jalil, and J. Shoenau. 1997. Use of hot $\mathrm{KCl}-$ $\mathrm{NH}_{4}-\mathrm{N}$ to estimate fertilizer $\mathrm{N}$ requirements. Can. J. Soil Sci. 77:161-166.

Chan, K.Y. 1997. Consequences of changes in particulate organic carbon in vertisols under pasture and cropping. Soil Sci. Soc. Am. J. 61:1376-1382.

Chalk, P.M., and S.A. Waring. 1970. Evaluation of rapid tests for assessing nitrogen availability in wheat soils. 1 . Correlation with plant indices of availability obtained in pot culture. Aust. J. Exp. Agric. Anim. Husb. 10:298-305.

Clay, D.E. and G.L. Malzer. 1993. Comparison of two chemical methods for extracting residual $\mathrm{N}$ fertilizer. Biology Fertil. Soils 15:179-184.

Curtin, D., and G. Wen. 1999. Organic matter fractions contributing to soil nitrogen mineralization potential. Soil Sci. Soc. Am. J. 63:410-415.

Dendooven, L., R. Merckx, and K. Vlassak. 1995. Limitations of a calculated $\mathrm{N}$ mineralization potential in studies of the $\mathrm{N}$ mineralization process. Plant Soil 177:175-181.

Doran, J.W., and T.B. Parkin. 1994. Defining and assessing soil quality. p. 3-21. In J.W. Doran et al (ed.) Defining soil quality for a sustainable environment. SSSA, Madison, WI.

Fisher, D.S., J.C. Burns, and K.R. Pond. 1989. Kinetics of in vitro cell-wall disappearance and in vivo digestion. Agron. J. 81:25-33.

Franzluebbers, A.J. 1999. Potential C and N mineralization and sequestration from intact and increasingly disturbed soils of varying texture. Soil Biol. Biochem. 31:1083-1090.

Franzluebbers, A.J., R.L. Haney, C.W. Honeycutt, H.H. Schomberg, and F.M. Hons. 2000. Flush of carbon dioxide following rewetting of dried soil relates to active organic pools. Soil Sci. Soc. Am. J. 64:613-623.

Franzluebbers, A.J., R.L. Haney, C.W. Honeycutt, M.A. Arshad, H.H. 
Schomberg, and F.M. Hons. 2001. Climatic influences on active fractions of soil organic matter. Soil Biol. Biochem. 33:1103-1111.

Gallagher, P.A., and M.V. Bartholomew. 1964. Comparison of nitrate production and other procedures in determining nitrogen availability in south-eastern Coastal Plain soils. Agron. J. 56:179-184.

Gianello, C., and J.M. Bremner. 1986a. A simple chemical method for assessing potentially mineralizable organic nitrogen in soil. Commun. Soil Sci. Plant Anal. 17:195-214.

Gianello, C., and J.M. Bremner. 1986b. Comparison of chemical methods of assessing potentially available organic nitrogen in soil. Commun. Soil Sci. Plant Anal. 17:215-236.

Gianello, C., and J.M. Bremner. 1988. A rapid steam distillation method of assessing potentially available organic nitrogen in soil. Commun. Soil Sci. Plant Anal. 19:1551-1568.

Greenfield, L.G. 2001. The origin and nature of organic nitrogen in soil as assessed by acidic and alkaline hydrolysis. Eur. J. Soil Sci. 52:575-583.

Griffin, T.S. 2008. Nitrogen availability. p. 616-646. In J.S. Schepers and W.R. Raun (ed.) Nitrogen in agricultural soils. Agron. Monogr. 49. ASA, CSSA, SSSA, Madison WI.

Groot, J.J.R., and V.J.G. Houba. 1995. A comparison of different indices for nitrogen mineralization. Biol. Fertil. Soils 19:1-9.

Hadas, A., S. Feigenbaum, A. Feigin, and R. Portnoy. 1986a. Distribution of nitrogen forms and availability indices in profiles of differently managed soil types. Soil Sci. Soc. Am. J. 50:308-313.

Hadas, A., S. Feigenbaum, A. Feigin, and R. Portnoy. 1986b. Nitrogen mineralization in profiles of differently managed soil types. Soil Sci. Soc. Am. J. 50:314-319.

Hassink, J. 1994. Active organic matter fractions and microbial biomass as predictors of N mineralization. Eur. J. Agron. 3:257-265.

Jalil, A., C.A. Campbell, J.J. Schoenau, J.L. Henry, Y.W. Jame, and G.P. Lafond. 1996. Assessment of two chemical extraction methods as indices of available nitrogen. Soil Sci. Soc. Am. J. 60:1954-1960.

Jenkinson, D.S. 1966. Studies on the decomposition of plant material in soil: II. Partial sterilization of soil and the soil biomass. J. Soil Sci. 17:280-302.

Juma, N.G., E.A. Paul, and B. Mary. 1984. Kinetic analysis of net nitrogen mineralization in soil. Soil Sci. Soc. Am. J. 48:753-757.

Keeney, D.R. 1982. Nitrogen-availability. p. 711-733. In A.L. Page et al (ed.) Methods of soil analysis. Part 2. Chemical and microbiological properties. Agron. Monogr. 9. ASA and SSSA, Madison, WI.

Keeney, D.R., and D.W. Nelson. 1982. Nitrogen-Inorganic forms. p. 643698. In A.L. Page et al (ed.) Methods of soil analysis. Part 2. 2nd ed. ASA and SSSA, Madison, WI.

Keeney, D.R., and J.M. Bremner. 1966. Comparison and evaluation of laboratory methods of obtaining an index of soil nitrogen availability. Agron. J. 58:498-503.

Kettler, T.A., J.W. Doran, and T.L. Gilbert. 2001. Simplified method for soil particle-size determination to accompany soil-quality analyses. Soil Sci. Soc. Am. J. 65:849-852.

Khan, S.A., R.L. Mulvaney, and R.G. Hoeft. 2001. A simple test for detecting sites that are nonresponsive to nitrogen fertilization. Soil Sci. Soc. Am. J. 65:1751-1760.

Kieft, L.T., E. Soroker, and M.K. Firestone. 1987. Microbial biomass response to a rapid increase in water potential when dry soil is wetted. Soil Biol. Biochem. 19:119-126.

Marion, G.M., J. Kummerow, and P.C. Miller. 1981. Preditcing nitrogen mineralization in chaparral soils. Soil Sci. Soc. Am. J. 45:956-961.

Nelson, D.W., and L.E. Sommers. 1996. Total carbon, organic carbon, and organic matter. p. 961-1010. In D.L. Sparks et al (ed.) Methods of soil analysis. Part 3. SSSA Book Ser. 5. SSSA and ASA, Madison, WI.

Øien, A., and A.R. Selmer-Olsen. 1980. A laboratory method for evaluation of available nitrogen in soil. Acta Agric. Scand. 30:149-156.
Paustian, K., and T.A. Bonde. 1987. Interpreting incubation data on nitrogen mineralization from soil organic matter. p. 101-112. In J.H. Cooley (ed.) Soil organic matter dynamics and soil productivity. Proceedings of INTECOL Workshop. Athens, GA.

Picone, L.I., M.L. Cabrera, and A.J. Franzluebbers. 2002. A rapid method to estimate potentially mineralizable nitrogen in soil. Soil Sci. Soc. Am. J. 66:1843-1847.

SAS Institute Inc. 2008. Statistical analysis system. Version 9.2 SAS Inst. Inc., Cary, NC.

Schomberg, H.H., and M.L. Cabrera. 2001. Modeling in situ N mineralization in conservation tillage fields: Comparison of two versions of the CERES nitrogen submodel. Ecol. Modell. 145:1-15.

Schomberg, H.H., D.M. Endale, A. Calegari, R. Peixoto, M. Miyazawa, and M.L. Cabrera. 2006. Influence of cover crops on potential nitrogen availability to succeeding crops in a Southern Piedmont soil. Biol. Fertil. Soils 42:299-307.

Selles, F., C.A. Campbell, B.G. McConkey, S.A. Brandt, and D. Messer. 1999. Relationships between biological and chemical measures of $\mathrm{N}$ supplying power and total soil $\mathrm{N}$ at field scale. Can. J. Soil Sci. 79:353-366.

Sharifi, M., B.J. Zebarth, D.L. Burton, C.A. Grant, S. Bittman, C.F. Drury, B.G. McConkey, and N. Ziadi. 2008. Response of potentially mineralizable soil nitrogen and indices of nitrogen availability to tillage system. Soil Sci. Soc. Am. J. 72:1124-1131.

Sharifi, M., B.J. Zebarth, D.L. Burton, C.A. Grant, and J.M. Cooper. 2007. Evaluation of some indices of potentially mineralizable nitrogen in soil. Soil Sci. Soc. Am. J. 71:1233-1239.

Smith, C.J., Chalk, P.M., Crawford, D.M., Wood, J.T., 1994. Estimating gross nitrogen mineralization and immobilization rates in anaerobic and aerobic soil suspensions. Soil Sci. Soc. Am. J. 58:1652-1660.

Soon, Y.K., A. Haq, and M.A. Arshad. 2007. Sensitivity of nitrogen mineralization indicators to crop and soil management. Commun. Soil Sci. Plant Anal. 38:2029-2043.

Sorensen, L.H. 1974. Rate of decomposition of organic matter in soil as influenced by repeated air drying-rewetting and repeated additions of organic material. Soil Biol. Biochem. 6:287-292.

Springob, G., and H. Kirchmann. 2003. Bulk soil C to N ratio as a simple measure of net $\mathrm{N}$ mineralization from stabilized soil organic matter in sandy arable soils. Soil Biol. Biochem. 35:629-632.

Stanford, G. 1978. Evaluation of ammonium release by alkaline permanganate extraction as an index of soil nitrogen availability. Soil Sci. 126:244-253.

Stanford, G., and S.J. Smith. 1972. Nitrogen mineralization potentials of soils. Soil Sci. Soc. Am. J. 36:465-472.

Stanford, G., and S.J. Smith. 1976. Estimating potentially mineralizable soil nitrogen from a chemical index of soil nitrogen availability. Soil Sci. 122:71-76.

Vanotti, M.B., S.A. Leclerc, and L.G. Bundy. 1995. Short-term effects of nitrogen fertilization on soil organic nitrogen availability. Soil Sci. Soc. Am. J. 59:1350-1359.

Wang, W.J., and R.G. Li. 1991. Evaluation of the methods for determining available nitrogen in soil on Hebei plain. Chinese J. Soil Sci. 22:263-266.

Wang, W.J., C.J. Smith, P.M. Chalk, and D. Chen. 2001. Evaluating chemical and physical indices of nitrogen mineralization capacity with an unequivocal reference. Soil Sci. Soc. Am. J. 65:368-376.

Wang, W.J., C.J. Smith, and D. Chen. 2003. Towards a standardized procedure for determining the potentially mineralizable nitrogen of soil. Biol. Fertil. Soils 37:362-374.

Waring, S.A., and J.M. Bremner. 1964. Ammonium production in soil under waterlogged conditions as an index of nitrogen availability. Nature 201:951-952.

Whitehead, D.C. 1981. An improved chemical extraction method for predicting the supply of available nitrogen. J. Sci. Food Agric. 32:359-365. 